情報管理 Vol. 27 No. 12 Mar. 1985

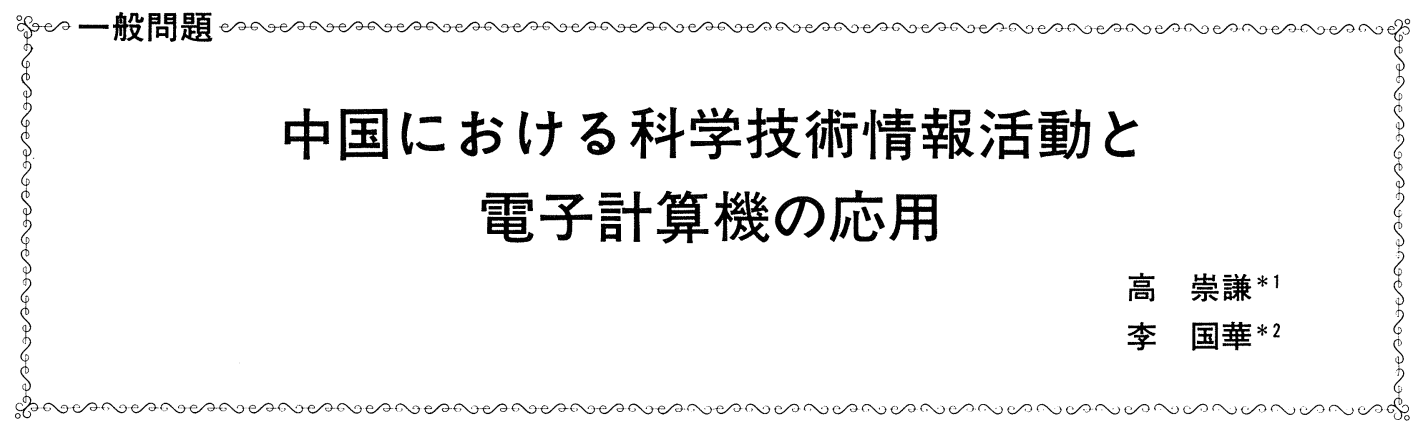

〔抄録〕「科学技術長期発展計画」に基づき現在まで 6 回にわたっって開催された「全国科学 技術情報工作会議」を中心に, 中国における科学技術情報活動の歴史的発展の過程を概説 した。1956 年に始動した科学技術情報活動は, 初期発展の 10 年, 文化大革命の 10 年を経 て新しい発展を遂げつつある。全国的情報組織がほぼ完成したとし, 情報の収集と提供, 情報検索サービス, 標準化, 人材の育成の現況を紹介。また, 情報部門, 図書館における コンピュータ利用の状況を詳述した。

\section{1. 発展の経緯}

中国の科学技術情報活動は，広義で言えば長い 歴史を持っている。歴史資料によれば最も早く図 書抄録の仕事に携わったのは西漢時代の刘向（紀 元前 $77 \sim 6$ 年）という人物だったそうである。彼 は図書について分類，目録，注釈および抄録を行 つた。その後，1780 年代に完成された『四庫全書 総目提要』は, 中国の古い書物の中でも最も有名 な経典抄録誌の一つである。

1934 年に至って近代的な科学技術抄録刊行物 が出版された。例えば，その当時の中国化学会が 編集した刊行物『化学』には「中国化学撮要」と いうタイトルで国内で発表された化学文献の抄録 が揭載され，化学文献情報の交流を促すうえで重 要な役割を果たした。

1949 年に新中国が成立したとき，中国には専門 的な科学技術情報機関が一つもなかった。1953 年 には科学出版社が 4 種類の生物科学関係の抄録誌
を定期的に出版し始め，中国科学院と各専門分野 の研究所も相次いで情報に関するある程度の活動 を開始した。しかし，その時点での情報活動はま だ散発的で分散状態にあり，全体的な計画を欠い ていたのである。

1956 年, 「科学技術長期発展の 12 か年計画」を 作成し, 科学技術を発展させるために情報活動は 欠くことができないとし，一つの緊急措置として 情報活動を「12 か年計画」の第 57 項目に盛り込ん だ。そして中国科学院に科学技術情報所を設置し, 国内外の科学技術資料を収集して抄録・速報・索 引誌等を編集・出版することとなった。

1958 年 5 月, 国務院は国家科学企画委員会およ び国家技術委員会が提出した「科学技術情報活動 の実行案」を承認した。これによって科学技術情 報所の基礎を固め, 科学技術情報事業の全国的七 ンターとして「中国科学技術情報研究所」と改称 L, 中国科学院と国家科学技術委員会 (国家科学 企画委員会と国家技術委員会が合併した）の二重
* 1 Gao, Chong qian

* 2 Li, Guo hua
中国国家科学技術委員会 科学技術情報局 助理研究員 中国科学技術情報研究所 計算机室 助理館員 
の指導を受けるようになった。「実行案」には全国 科学技術情報システムを構築し, 専門別, 地域別 の科学技術情報機構を発展させる方策が詳しく規 定されている。

同年，国務院は国家科学技術委員会に科学技術 情報局を設置することを承認した。これは情報管 理の統一的な企画を立てたり，全国科学技術工作 の協力体制を組織したりする機構である。その後, 国務院の各部門，省，市，自治区では相次いでそ れぞれのレベルでの情報機構を設立していった。

1958 年以後, 次のような 6 回にわたる全国的な 科学技術情報工作会議が開催された。

（1）第 1 回 全国科学技術情報工作会議 （1958 年）

この会議において，国家科学技術委員会付主任で ある武衡は「さらに科学技術情報工作を固めよう」 という報告を行った。この中で，1962 年までにで きるだけ「12 か年計画」を完成して全国科学技術 情報ネットワークを建設し，あらゆる力を組織し て情報活動を促進し，情報研究を展開すべきであ るなどの重要な意見を述べた。会議では科学技 術情報活動は迅速に広く正しく社会主義建設の総 路線に奉仕しなければならないという方針と，科 学研究・生産に奉仕するための具体的な任務を決 めた。

（2）第 2 回 全国科学技術情報工作会議 （1961 年）

この会議では，科学技術情報活動の中で貫徹すべ きことは機構の調整であるという「方針」を打ち 出し,「独立自主·奮発図強」という精神を発揚す ることが強調された。この会議以後, わが国の科 学技術情報機構は外国の多くの情報機関と科学技 術資料を交換する関係を確立し, 情報提供の拡大, サービスの質と効果の向上, 情報担当者の教育レ ベルの向上など種々の面において多くの仕事を行 った。

（3）第 3 回 全国科学技術情報工作会議 (1963 年)

この会議で国家科学技術委員会付主任の武衡は, 2 年来の全国科学技術情報工作についての総括報
告を行い，国内の科学技術情報の流通を強固にす べきであると強調した。わが国の「1963〜1972 年 における科学技術発展計画」の第 54 項目に, 重要 な内容として科学技術情報活動を盛り込んだ。 科学技術情報活動は, 国民経済の発展計画と科 学技術発展 12 か年計画を相互にしっかりと連携 させなければならないし，60 年代に発展した新し い科学技術を速やかに習得して, 近代化を実現す るために奉仕しなけれげならないとした。

（4）第 4 回 全国科学技術情報工作会議 (1975 年)

この会議では, 科学技術情報ネットワークを強化す ることを決めた。さらに「全国科学技術情報工作 企画」の作成, 協力関係の組織化, 実務者間の経 験の交換，業務指導の実施を中国科学技術情報所 に委任することになった。1978 年 4 月, 全国科学 大会を通過した「1978～1985 年における全国科学 技術発展のための計画綱要 (草案) 」に基づき，「近 代的な技術でわが国の主要な部門と地区に情報 所・図書館を設置し，「配置合理・分工協作」とい うような全国的情報・図書館システムを建設して， 情報と図書館活動の理論と方法, および新しい技 術と設備を研究しようという要求を出した。これ によって, 1978 年 8 月, 中国科学技術情報学会が 正式に発足した。

(5) 第 5 回 全国科学技術情報工作会議 (1980 年)

国家科学技術委員会付主任の江明が第 4 回科学技 術情報工作を総括して, 科学技術情報は国民経済 に奉仕すべきだという方針を提案した。科学技術 情報活動を強化することは国民経済を振興させる という要請に合致するわけである。

（6）第 6 回 全国科学技術情報工作会議 (1984 年)

国家科学技術委員会副主任の楊浚は会議で「あら ゆる機会をとらえて, 科学技術情報工作を強化し， もっと効率的に経済建設に奉仕しよう」という報 告を行った。情報工作を強化する措置として, 国 家科学技術委員会に科学技術情報局を再び設置し た（1958 年に設置された科学技術情報局は文化大 
革命で消滅した)。科学技術情報局の任務は, 全国 科学技術情報活動の方針・政策の策定, 計画の立 案, 協力関係の組織化, 業務指導, 幹部の教育等 である。会議ではこれまでの経験を総括し交換し あって，今後の方向と任務を明らかにするととも に，全国科学技術情報検索システム計画について 討議した。科学技術情報は国家経済建設のために 貢献しなければならないということが重ねて強調 された。

この 6 回にわたる会議はわが国の発展の各時期 における科学技術情報活動の方針・任務と計画を 討論し, 成案化したばかりでなく, 情報活動発展 の各歴史段階の歩みをも物語っている。特にこの 数年来, 全中国における科学技術情報活動は各方 面で著しい社会的・経済的効果を上げ，活況を呈 している。

\section{2. 科学技術情報活動の現状}

中国の科学技術情報活動は 1956 年に発足し, 現 在すでに 28 年の歳月が経過した。それは創成・強 化・発展の 10 年, 「文化大革命」による厳しい試 練を受けた 10 年, および復興・再発展のここ数年 という三つの段階を経て, 今日に至った。以下に いくつかの角度から簡単にわが国の科学技術情報 事業の新しい状況を紹介する。

\section{1 情報機構と人員}

28 年間の努力によって, わが国の科学技術情報 システムがほぼ出来上がった。目下，国務院の各 部・省クラスに位置付けられる科学技術情報研究 所は 72 機関 (そのうち国務院の部クラスに相当す るものは 43 機関, 省クラス相当は 29 機関), 地方 行政単位の科学技術情報機関は 219 であり，その 他多くの科学研究所, 高等学校, 学院や企業にも 情報処 (室) が置かれている。全国レベル, 地区レ ベルおよび企業の専門情報ステーションを加える と, 科学技術情報網は 3,000 か所に達する。これ らの機関で働く科学技術情報専任職員は約 6 万人 で，兼務者をも加えると，約 10 万人に達する。6
万人の専任職員のうち情報業務従事者は 4 万 8,000 人で, 事務従事者は約 1 万 3,000 人である。この 数字から見ても, 近年, 中国の情報活動は組織面 でも大きな発展を遂げたことがわかるであろう。

\section{2 情報資料の収集}

各時期の国民経済と科学技術発展の要請に対応 して，各レベルの情報機関はそれぞれの任務に従 い，広く国内外の科学技術情報資料を収集してき た。ある調査によれば，1982 年に中国で収集した 外国逐次刊行物は約 1 万 8,000 種類で，世界の科 学技術逐次刊行物総数（5 万種と推定）の 3 分の 1 にあたる。特許文献は約 60 万件, 世界の特許文 献総数 (100万件と推定)の 3 分の 2 にのぼる。規 格資料は 56 か国より延べ 35 万件である。そのほ か, 研究レポート, 会議論文, 技術規格, 力夕口 グ，科学技術映画，ビデオテープ等も大量に収集 している。

1982 年, 中国では約 4,000 種類の逐次刊行物を 出版した。定期・不定期の情報学刊行物は 31 種類 で, 図書館学刊行物は 42 種である。現在, わが国 は 60 か国と文献資料の交換をしており, 情報源を 大きく拡大した。

\section{3 情報資料の提供}

中国では 1956 年からソ連の抄録誌の翻訳・出版 を開始したが，次第に自国で編集した抄録誌を増 加させてきた。1966 年の統計によれば全国で出版 された二次資料は 139 種類に達しており，そのう ち，抄録誌は 100 種類であった。「10 年動乱」の間 に多くの二次資料は相次いで休刊となった。1977 年 7 月, 科学技術文献二次資料の協調会議を開催 してから, 全国科学技術文献刊行物が復刊され, 新しい発展が可能となった。

1983 年の全国文献編集委員会の統計によれば, 全国の二次資料刊行物は 159 種にのぼり, 年間提 供記事量は 105 万件であった。そのうち, 国内科 学技術文献の刊行物は 33 種類 (抄録類 13 , 目次類 20), 記事 19 万件, 国外文献の二次刊行物は 101 種 (抄録類 67 , 目次類 34 ), 記事 76 万件, 国外特 
許文献は 25 種，記事 10 万件であった。

これまで述べた二次資料は扔招むねよく体系化 されているとはいえ, やはり多くの問題が内在し ている。例えばカバーしている専門分野が不完全 であること, 出版のサイクルが比較的長いこと, 内容が重複したり漏れがあったりすること，など である。二次資料の質を向上させるためにいろい ろな措置を講じつつある。

\section{4 検索サービス}

現在の中国での文献検索は，主としてマニュア ルである。つまり，種々の国内外の目次誌や抄録 索引誌等の検索ツールを利用して資料の手掛かり を見つけ，読者の要求する資料を提供している。 このような方法に限られていたため，わが国の情 報サービスはユーザの需要を満足させることがな かなかできなかった。

そこで検索サービスの質をより向上させるため に，1976 年の初めから外国の文献検索用磁気テー プを 32 種類継続的に導入し, S D I サービスを行 うこととした。1982 年には検索プロファイルは 9,000 件に達した。北京計算センターと北京文献 サービス処が外国の磁気テープを利用してオンラ インサービスを行った。都市・農村建設環境保護 部に属する科学技術情報所等の機関は，北京と香 港にアメリカのDIALOGとORBITシステムの 端末を設置していた。

1983 年 9 月 1 日加, 中国科学技術情報研究所 $と$ ESA-IRS (European Space Agency-Information Retrieval Service) とは, EURONET とアメ リカの TYMNETおよびTELENETを経由し て，全中国のユーザにオンライン検索サービスを 開始した。同年 10 月の統計によれば，検索プロフ アイル数は延べ 387 ，ヒット文献は 5,541 件であ り，国家からの補助金の下でユーザ質問 1 件約 60 元人民幣（日本円で 6,600 円）の検索費用を徵収 している。

\section{5 文献の標準化}

標準化は情報学と図書館学の重要な仕事の一つ
である。標準化によって文献処理を規格化・統一 化し, 労働の重複を最小限にとどめることができ, 科学技術情報の流通, 情報技術の応用を促進する ことによって経済効果を高め，情報資源の共同利 用という目的を達成することが可能となる。

中国の実情から見れば，文献の標準化事業は比 較的遅れており，発展のスピードも遅いようであ る。1979 年,「文献工作標準化技術委員会」が設立 されてから，文献標準化事業を促進し，その発展 が速如られた。4 年間の努力によって中国国家標 準局が制定した実用国家規格は，あわせて下記の 14 件である。

(1) GB 788一65「図書・雑誌の寸法」

(2) GB 1.2-81「技術標準出版印刷の規程」 (改訂)

(3) GB 2261-80「人間の性別コード」

(4) GB 2261-82「中華人民共和国行政区画コ ード」

（5）GB 2659-81「世界各国㧍よび地域の名称 コード」

（6） GB 2901-82「文献目次情報交換用磁気テ ープフォーマット」

（7） GB 3259-83「中文書刊名称の漢語拼音の 書き方」

（8） GB 3179-83「科学技術逐次刊行物植字組 み合わせ規程」

（9） GB 3304-82「中国各民族名称のアルファ ベットの書き方とコード」

(10) GB 3468-82「二次逐次刊行物編集総則」

(11) GB 3469-82「文献タイプと媒体コード」

(12) GB 3792.1-83「文献書誌的事項の規則」

(13） GB 3793-83「二次逐次刊行物収録項目規 則」

(14) GB 3860-83「文献主題索引規則」

確かに，これらの国家規格はわが国の文献活動 の標準化に貢献することは間違いないが，先進諸 国に比べると数量的にも質的にも大きな格差があ るので，現在，現実的な措置を講じつつ，文献標 準化を推進しているところである。 


\section{6 人材の㕕成}

優れた科学技術情報の人材を育成することは, 情報事業を振興するための重要な戦略の一つであ る。目下，わが国は数において決して少なくない， 素質ある科学技術分野の人材を有し, 彼らは科学 技術情報事業の発展過程で大きく貢献した。しか し, 新しい時代の新しい要求にはなかなか適応で きなかった。

知識の面から見ると, 年長の情報担当者は豊か な経験を持っているものの, 時代に合う有効な教 育を欠き, 彼らの知識が速やかに更新されなかっ たため, 情報事業を発展させる新しい情勢に追随 できなかった。若い情報担当者は厳しい情報業務 の基本的な訓練を欠いていただけでなく，情報処 理に関する経験も乏しいから，ユーザの需要にも 対応できないのである。

そのため, 近年来多くの地方および専門の情報 所はいろいろな形式で情報処理業務に関する講座 を開催している。いくつかの高等教育機関, 例え ば北京大学, 武漢大学, 上海師範大学, 吉林工業 大学等も情報学科, 情報研究室を設置して, 数多 くの人材を育成してきた。ある統計によれば, 1981 年に専門情報センターの職員は 1961 年より約 6.5 倍, 地方情報センターの職員は約 5 倍増えて 質も向上した。

現在, 国家科学技術委員会が科学技術情報の幹 部を育成するために教育計画を作成し, 積極的に 在職人材の教育に励んでいるので, 近い将来には, わが国の情報専門家集団は大きく増強されるもの と思われる。

\section{3. コンピュータの応用}

わが国の情報部門・図書館において，コンピュ 一夕は主として情報検索, 業務管理および機械翻 訳の研究に使われている。この現状について以下 に紹介する。

\section{1 情報検索の歴史}

早くも 60 年代の初めにわが国は機械検索言語
とその設備についての研究を始めた。その当時, 設備としては主に光電式の検索機と漢字ラインプ リン夕の研究を行ったが，この仕事はまもなく調 整（機構, 人事, 経済の企画の調整）という任務 のために中断した。

1962 年 1 月, 中国科学技術情報研究所では新方 法研究室を設置した。1963 年にBULLというフ ランス製のコンピュータを統計・分析のために購 入し，パンチカードによる機械検索の研究を展開 していた。その後, 旧第一機械工業部をはじめと して，いくつかの情報機構にも機械検索の研究グ ループが組織され, 専門家によって情報検索法の 研究が行われた。

しかし全中国において，着実で，計画的・組織 的に機械検索の研究が始められたのは 1974 年末 であった。1974 年 9 月の国家計画委員会において 承認された計画に従って, 中国科学技術情報研究 所は日本の高千穂 T 4100 漢字システムと, 主機 としてTK 70 コンピュータを導入した。

できるだけ早くコンピュータによる文献検索を 実現するのに必要な条件を作るために，中国科学 技情報研究所と北京図書館が中心となり，505 機 関の協力によって中国語主題キーワード表が編集 された。北京文献服務処はいちばん早く国外の市 販二次文献検索用磁気テープG R A (Government Reports Announcement）を購入して，欧文文献 のコンピュータによる検索の研究を行うことによ つて，絶えず経験を蓄積してきた。

1975 年末, 北京文献服務処は北京航空学院計算 センターの FILIX 50 コンピュータを使って，情 報検索の実験を行い, 1976 年に成功を遂げた。そ の後, 機械工業部情報所, 化学工業部情報所, 南 京大学, 北京文献服務処等は相次いで, 国外の文 献検索磁気テープを利用したＳＤＩサービスとオ ンライン検索の試験を行った。それ以後, 全中国 において多くの情報部門が国外の欧文文献データ ベース（磁気テープ）を対象とした種々の機械検 索システムを開発した。コンピュー夕による検索 に必要な知識を普及するために, 1980 年 5 月, 中 国科学技術情報所からわが国における初めてのコ 
ンピュータ検索に関する下記の図書を出版した。 曾民族，高崇謙編：情報工作での電子計算機の 応用 北京科学技術文献出版社 1980 年 4 月 この図書の内容の大部分は JICST の『情報管理』 第 16 巻に連載された「計算機実務講座」によって いる。この図書の出版は中国におけるコンピュー 夕検索システムの開発に貢献した。

1980 年以降, コンピュー夕利用による情報サー ビス事業は急速な発展を遂げた。たとえば，都市 建設情報所の提案に基づき，中国建築技術発展セ ンター情報所などの機関はアメリカのDIALOG やORBIT 検索用の端末を香港に設置したほか, 石油部情報所は北京に国際オンライン端末を設置 し，オンライン検索サービスを行っていた。北京 文献服務処が UNIVACコンピュータと UNIDAS オンライン検索プログラムを導入して，1982 年 6 月から NTIS の GRA テープを用いた本格 的な検索サービスを開始した。

1983 年, 中国科学技術情報所は日本から導入し たTK 70 コンピュータシステムで, 初めて中国語 の『中国薬学文摘』を編集, 印刷することができ た。また試験的漢字文献検索をも実現した。同年 9 月 ESA-IRS と提携して, 北京に ESA オンラ イン端末機を設置し, 現在, 正式にユーザにサー ビスしている。

わが国でのコンピュータによる情報検索事業の 振興という観点からみて，コンピュータは次のい くつかの面で応用されつつある。

(1) 外国文献磁気テープを十分に利用すると同 時に自国の漢字データベースを作成する。この二 つの組み合わせによって補完し合う。

(2) 文献検索から図書の購入, 資料管理, 給料計 算等の業務管理にまで利用範囲が広がっている。

(3) 大型の情報検索システムが構築される一方, マイクロコンピュータは, 值段が安く, 機能が優 れ, 操作が簡単である等の長所のために, 中小規 模の図書・情報機構においてますます広く使われ 始めている。マイクロコンピュー夕はこれからの オフィスオートメーションの実現に強力な基礎を 与えるものである。

\section{2 コンピュータ応用の実例}

(1) 漢字薬学文献処理システム

このシステムは中国科学技術情報研究所と国家 医薬管理局医薬技術情報研究所によって開発され たもので，1981 年 3 月から 1982 年 6 月にかけて の TK 70 コンピュータと漢字 T 4100 システムを 使ってテストし，成功を収めた。

コンピュータ編集による『中国薬学文摘』とい う漢字の二次資料が出版された。これは 1983 年以 降に国内で発行された約 100 種の逐次刊行物に掲 載された漢方薬, 合成薬, 生化薬品等に関する文 献を紹介するもので，提供量は年間約 1,000 件, 主題, 著者名, 機関名と外国語薬名からの 4 種の 索引がついている。

このシステムは主として次の三つのサブシステ ムからなっている。

(1) 記事ファイル作成システム インデクシングされた漢字薬学記事はパンチ 大力され, 校正後, 決まったレコードフォー マットで磁気テープに記録してデータベース を作成する。

(2)二次資料自動編集システム 磁気テープに記録したレコードの必要項目を 抽出して, 記事のシーケンシャルコードの昇 順でソートし，見出し・抄録・索引をそれぞ れの要求に従って植字製版し, ゲラ刷りを出 力する。

(3) 検索サブシステム ユーザのテーマを登録して, 該当文献を抽出 するバッチ検索である。

(2) 世界特許索引磁気テープ検索システム

1980 年, 上海市科学技術情報所の開発によるシ ステムで, $\mathrm{PDP}-11 / 34 \mathrm{~A}$ コンピュータ(主記憶 256 KB) を使って Derwent 社の WPI テープの SDI サービスを提供しているがバッチの遡及検 索サービスも可能である。これはシーケンシャル ファイル検索システムである。

検索プログラムは COBOL で書かれ, 次の四つ のサブプログラムからなっている。

(1) 検索タグ表作成プログラム 
検索キーとした項目をマスターテープから抽 出して定められたフォーマットに移してタグ 表を作成し，検索に使用する。夕グ表を作成 するプログラムを磁気テープ (遡及検索用), あるいは磁気ディスク（SDI 用）に記録する こともある。

(2) 質問ファイル作成プログラム

ユーザからの質問情報を質問ファイルに入力 する。レコードは固定長で, 磁気ディスクに 記録する。ユーザ情報にはユーザの所属機関, キーワードと質問論理式等が含まれる。

(3) 検索プログラム

タグ表での検索キーと質問ファイルの中の質 問とを比較照合して, 論理演算の後, ヒット した文献を出力する。

(4)プリントプログラム

ヒットした文献の記録をユーザリクエストコ ード順にソートして, 一定のフォーマットで プリントする。

\section{(3) 欧文書目検索システム}

清華大学図書館によって開発されたシステム で，1978 年 10 月から着手し，1980 年 6 月正式に 運用を開始した。DJS-130 (容量 $32 \mathrm{~KB}$ )という中 国製のコンピュー夕を用い, 磁気ディスクュニッ ト2台 (それぞれ $5 \mathrm{MB})$, 多重通信機とディスプ レイ端末機 4 台等で編成されている。そのほか, 拡張 BASIC または FORTRAN (ユーザが選択で きる), ライブラリーデータベース・マネジメント システム, およびリアルタイム・磁気テープ・オ ペレーションシステム $(\mathrm{RDOS}) の$ のポートによっ て科学計算, デー夕処理と事務管理等を行い得る 機能を持っている。

このシステムのアプリケーションプログラムは BASICで組んであり，次の三つのプログラムで 構成されている。

(1) 多重ユーザオンライン書目検索システム 多くの読者が所蔵目録データベースを会話形 でオンライン検索する場合に使う。

(2) 図書の流通管理用プログラム

図書の貸出と返却, 発注予約等の流通管理業
務に使う。

(3) 困書館の事務処理プログラム

給料の計算・人事資料の統計，手紙，封筒を プリントする場合に使う。

以上の機能を実現するため，それぞれ必要なフ アイルを作成した（例えば，読者ファイル，給料 データファイル, 人事資料ファイル, 通信メモフ アイル等)。このシステムは約 4 年間運用してい るがデータベースの容量, ハード・ソフトウエア の機能, サービスの範囲は1980 年当初より大幅に 向上した。

(4) MRIS マイクロコンピュータ文献検索シ ステム

これはアメリカの MRIS Abstracts (Maritime Research Information Service) をデータベース とする二次情報検索システムである。このデータ ベースには，3 年間の MRIS 抄録 9,000 件にキー ワードを付してありキーワードごとに文献のアド レスをつけてあるため, 一種のインバーテッドフ アイルとなっている（キーワード数は約 5,000 個)。

このシステムの設備は小型マイクロ資料検索機 とマイクロコンピュータから成っている。二段階 オンライン検索とは, キーワードを利用してマイ クロコンピータで第一段階の検索を行い, ヒット した文献のアドレス（第一段階の検索結果）をオ ンラインでマイクロ資料検索機に入力して，オリ ジナルの一次文献を見つけ，一定のフォーマット でコピーする。これはユーザにサービスを提供す る検索方式の一種類である。

このシステムのソフトウエアは拡張 BASIC で 書いたものであり，ファイル作成プログラムと検 索プログラムから成っている。

(1)ファイル作成プログラム

入力, フォーマット編集, 校正, ソート, マ 一ジ，更新等の機能を持っている。ファイル のレコードは固定長である。

(2) 検索プログラム

主題語で検索する場合, 出力の MRIS 文献索 引を編集・印刷する場合および『MRIS 主題 
語表』を編集，印刷する場合に使う。目下， このシステムは『MRIS 抄録誌』の文献を継 続して入力しているところであり，データべ 一スを 10 年まで拡充し, 文献を 3 万件蓄積す るつもりである。

\section{3. 機械翻訳の研究}

機械翻訳という課題は 1956 年にわが国の科学 活動発展計画に組み入れられた。それは「機械翻 訳と自然言語翻訳規則の開発および自然言語にお ける数学理論」という研究テーマであった。

1957 年に主としてロシア語から中国語, 英語か ら中国語への機械翻訳の研究を開始した。北京言 語研究所と科学院計算技術研究所および中国科学 技術情報所が協力して，ロシア語から中国語への 機械翻訳規則を開発した。1959 年, 国慶節 10 周年 の直前に 104 型という中国製の沉用コンピュータ によって試験を行い成功を収めた。その当時, 漢 字の出力設備がなかったため漢字の電報コードで 訳本を出力した。

1960 1961 年の間，前述の 3 機関が中心となっ て大学と研究機関 10 か所以上と共同して,これま での研究成果を基礎にしてさらに新しいシステム を開発した。1966１975 年までは文化大革命によ ク機械翻訳の研究が中断した。

1975 年 11 月, 中国科学技術情報研究所は北京 言語研究所と計算技術研究所等の部門からなる機 械翻訳連合研究組を設立した。この研究組の任務 は英語から中国語への機械翻訳を研究・実現する ことであったが，最初の目標は英語から中国語へ の治金専門文献のタイトル翻訳規則を開発するこ とであった。1978 年 5 月, 計算技術研究所の 111 型コンピュータでサンプル試験を行った。出力し た訳本は漢語拼音であった。

1978 年, 北京言語研究所では機械翻訳研究室を 設置した。黑龍江大学、哈爾浜工業大学、上海科 学技術情報所も相次いで機械翻訳グループと専門 家を置き，機械翻訳の研究を推進している。1978 年言語研究所, 計算技術研究所はそれぞれ機械翻 訳の研究生を募集した。
1981 年の初め, 中国科学技術情報所の TK 70 コンピュータを利用してバッチ形式での試験とし て治金文献タイトル 5,000 件を機械翻訳した。出 力の訳本は漢字である。精度は 80 パーセントであ ク, 残りの 20 パーセントは辞書と文法におけるミ スであった。

1982 年, 第 1 回全国機械翻訳学術討論会を開催 した。会議での論文発表や経験の交流は, 機械翻 訳の振興を促すために役立った。

またロシア語から中国語, フランス語から中国 語, ドイツ語から中国語への機械翻訳の研究も行 っている。

\section{4.おわりに}

20 数年来, わが国の科学技術情報事業はある程 度の発展を遂げたにもかかわらず，まだ次のよう な解決すべきいくつかの問題点を残している。

(1) 国情に沿った実際的効果を求めるために, 情 報サービスの範囲を拡大し，わが国の情報工作の 新しい道を開くこと。

(2) 計画的，段階的にコンピュー夕による全国的 で大規模な科学技術情報検索システムを開発する とともに, 中小企業で活用できるようなマイクロ コンピュータによる検索システムの開発に努力す ること。

(3) 科学技術情報の二次資料刊行システムをよ り充実して, 刊行物の質の向上と, タイムラグの 短縮を図ること。

(4) 科学技術に携わる要員の質の向上のために, 教育を強化すること, および情報専門家組織の充 実を図ること。これは情報事業において戦略的な 任務であるからその対策は急を要する。

\section{参考文献}

1）袁翰青：科学技術発展の歴史, 科学技術情報工作 テキスト 中国科学技術情報研究所, 上冊編, 1963 P. 6-12 
2）林自新：中国科学技術情報工作と情報での新し い技術の応用 1982 (講演)

3）刘春科, 郭厚光：中国語文献ファイルの作成と検 索刊行物の自動編集 情報学報 1〔2〕 193-199（'81）

4）陳秀莫, 顧躍芳：世界特許索引磁気テープの情報 検索試験 計算機と図書館（1）16-23（'81）

5）清華大学困書館：清華大学図書館における欧文
書目計算機補助検索システムについて 全国第二 回機械検索学術交流会論文 1982

6）一つの実用されたマイクロコンピュータ文献検 索システム 計算機と図書館（交通部情報所）（4） $5-10(' 81)$

7) 刘涌泉：機械翻訳の発展とわが国機械翻訳の特 長について 情報学刊（1）25-33（'80）

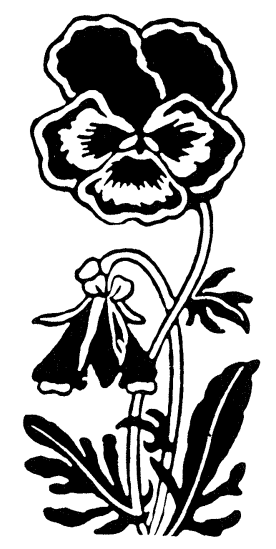

